\title{
The Arab Geologists' Association (AGA)
}

\author{
wisam@uruklink.net; wisam42@burntmail.com
}

\section{Definition}

The Arab Geologists Association (AGA) is a non-governmental pan-Arab geological organization founded in 1975 by geological commissions, i.e., geologists unions, geological societies, representing nine Arab countries, namely, Egypt, Palestine, Morocco, Jordan, Libya, Sudan, Lebanon, Tunisia and Iraq. Organizations of geologists in Syria and Yemen joined the Association shortly after.

\section{Objectives}

AGA was founded to achieve the following objectives:

a Endeavoring to promote the importance of the geological profession and to raise its scientific standard in order to meet the requirements of Arab geologists working in various fields;

b Studying geological problems and matters having mutual interests among Arab countries and exchanging information and experts in various vocational and technical fields;

c Supporting geological commissions existing in various Arab countries and assisting geologists to form commissions where such commissions have not yet been constituted;

d Raising the standard of Arab geologists morally and materially and promoting their scientific, practical and professional background;

e Communicating with international geological commissions and organizations and co-operating in all matters serving the Association's objectives.

AGA endeavors to achieve these objectives through:

a Organizing geological seminars, symposia and participating in similar Arab and international activities;

b Conducting study and research on geological problems in Arab homeland in general and endeavoring to publish their results;

c Organizing field studies for joint geological projects among Arab countries and endeavoring to execute them;

d Co-operating with official and semi-official institutions in Arab countries and with commissions and organizations emerging from the Arab League.

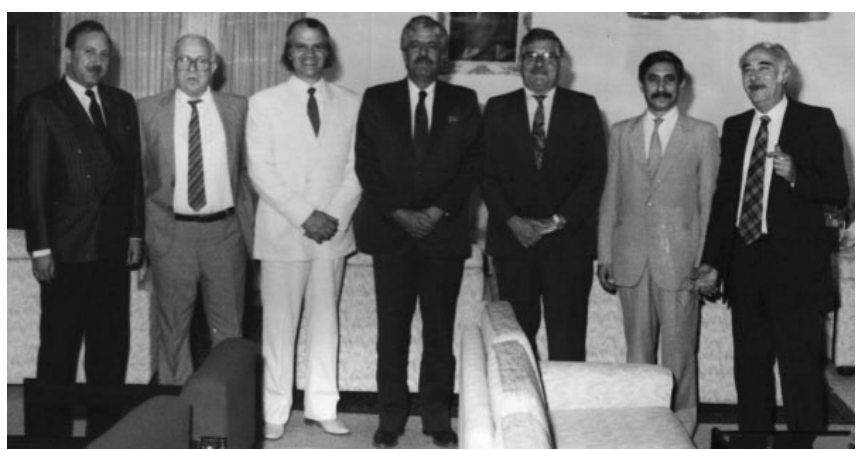

From right to left: Late A. Mohieddin (AGA Treasurer), Dr. F. Al-Hadad (Chairman, Iraqi Geologists Union), Mr. A. Al-Mahmood (Director, Petroleum Training Institute, Baghdad), Dr. S. Sheriff (Retiring AGA Secretary General), n Wiscam S Ml-Hashimi (AGA Somotary Gonorall

\section{Establishments}

The Association's establishments are :

1 The General Conference;

2 The Supreme Council;

3 The Executive Bureau;

4 The Secretariat General;

5 Permanent and Temporary Technical Committees.

Affairs of the Association are run by the Executive Bureau and the Secretariat General.

The Executive Bureau of the Association is composed of the Chairman, the Secretary-General and the representative of the geological commission in the Supreme Council of the country which has the next term for the Association's Chairmanship. Following recent amendments of the Association's Statutes the EB now consists of five members instead of three .

\section{Membership}

Membership of the Association was between 1975-1992 limited only to geological societies and geologists unions in Arab countries. However, because geologists in many other Arab countries have neither scientific nor professional organizations, they were not able to join the Association. To overcome this problem, the Supreme Council approved in December 1992 the introduction of two new membership categories. These are individual membership and institution membership. The latter is also open to foreign institutions, both geological and non-geological. Annual fee for individual Membership US\$ 50, and for institution membership :US\$300 in Arab countries, US\$500 in foreign countries.

Applicants may write to the Secretariat General for membership forms. Payment of membership fee is by check or bank transfer order to : Arab Geologists' Association, Account No. 125368 at the Jordan Islamic Bank, Saqf Al-Sael Branch, P.O.Box 182059, Amman, Jordan.

\section{AGA Sessions}

In the period between 1975-1998 the Supreme Council of the Association held five meetings during each new officers for the Executive Bureau were elected. The followings are the names of the officers of the five consecutive Sessions of the Executive Bureau :

\section{First Session}

1 Dr. Munir Al-Khuli-Chairman (Egypt)

2 Dr. Fallah S. Jaber - Vice Chairman (Palestine)

3 Dr. Sammi Sherif - Secretary General (Iraq)

\section{Second Session}

1 Dr. Fallah S. Jaber-Chairman (Palestine)

2 Dr. Ahmed Demnati-Vice Chairman (Morocco)

3 Dr. Sammi Sherif - Secretary General (Iraq)

\section{Third Session}

1 Dr. Ahmed Demnati-Chairman (Morocco) 


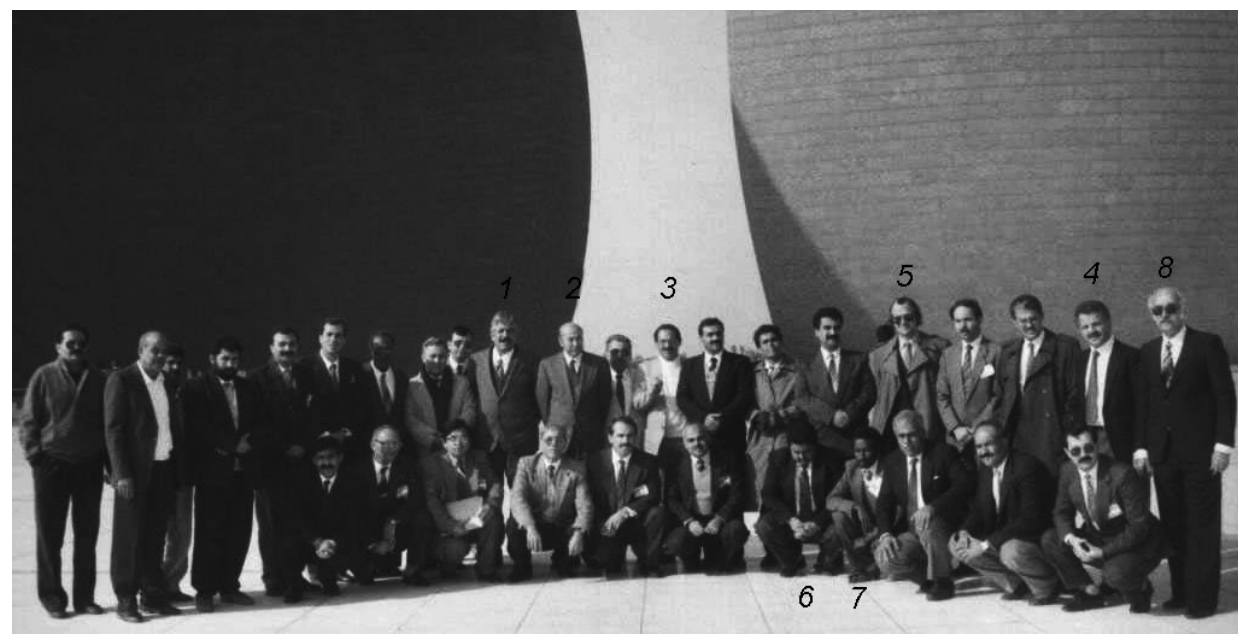

Delegates of geologists from Arab Countries to an AGA Council meeting gathered in front of the Martyr's Monument in Baghdad. (1) Retiring Secretary General Dr. S. Sheriff (Iraq), (2) Dr. A. Demnati, AGA Past President (Morocco), (3) Mr. George Hadadeen, AGA former Vice President (Jordan), (4) Mr. E. Abu Taha, AGA President-elect (Jordan), (5) Dr. W. S. Al-Hashimi, AGA Secretary General (Iraq); AGA Vice Presidents: (6) Mr. I. Oraibi (Libya), (7) Mr. S. A. Kader (Sudan), (8) Mr. A. Mohieddin, AGA Treasurer (Iraq).

Fourth Session

1 Mr. Issa Abu Taha and then M. Salim Dakhlalah-Chairman (Jordan)

2 Mr. Ibrahim A. Oraibie - Vice Chairman (Libya)

3 Dr. Wissam S. Al-Hashimi-Secretary General (Iraq)

\section{Fifth Session}

1 Mr. Ibrahim A. Oraibie-Chairman (Libya)

2 Mr. Sideek A. K. Khojali-Vice Chairman (Sudan)

3 Dr. Khalid Al-Subai Vice President (Yemen)

4 Dr. Wissam S. Al-Hashimi-Secretary General (Iraq)

\section{Scientific activities}

The Association organized, sponsored and co-sponsored the following scientific activities, listed in chronological order :

1 Symposium on Marble Industry in the Arab World, Rabat, 1978;

2 First Geological Congress on the Middle East (GEOCOME-I), Ankara, 1979;

3 First Arab Seismological Seminar, Baghdad, 1979;

4 First Arab Seminar on Underground Storage, Baghdad, 1979;

5 Second Arab Seismological Seminar, Rabat, 1981;

6 Second Geological Congress on the Middle East (GEOCOMEII ), Baghdad, 1983;

7 Second Arab Seminar on Underground Storage, Amman, 1983;

8 First Arab Conference on Geological Education, Baghdad, 1986;

9 Symposium on the Application of Computers in Geological Sciences, Baghdad, 1986;

10 Conference on Recent Sediments of the Arabian Gulf, Kuwait, 1987;

11 Symposium on Geology and Urban Development, Baghdad, 1994;

12 International Conference on Coastal Environments of Northern Arabian Gulf, Basrah, 1994;

13 Third Geological Conference on the Geology of the Middle East (GEOCOME-III), Amman, 1994;
16 Symposium on Geological Correlation Between Arab Countries: The Paleazoic II, Beirut, 1998;

17 Symposium on the History of Earth Sciences in Arab \& Muslim Countries: Origin, Development Utilizations, Baghdad, 2000;

18 Fifth Geological Congress on the Middle East, Cairo, 2003.

The Association is working now on the organization of several events and these are:

19 Symposium on Gypsum Soil of the Middle East (Gypcrete), Dec. 2003 (Had to be postponed following the U.S. invasion of Iraq);

20 Sixth Geological Congress on the Middle East, Abu Dhabi, Jan. 2006;

21 Underground Energy Storage, Bahrain, 2005

\section{Publications}

The Association has managed to publish proceedings of some of the a. m. meetings which are available from the Secretariat General.The Association publishes a bilingual (Arabic-English) quarterly geoscience newsmagazine, Geoscience \& Arab Development. The newsmagazine publishes articles and researches on the application of geoscience for development in Arab countries and elsewhere. The newsmagazine also publishes:

- News of Arab oil industry

- News of Arab mineral industry

- News of Arab water

- List of new geological literature

- Conference reports

- Prices of metals, industrial rocks \& minerals

- Advertisement

Annual subscription rate (including postage):US\$ 100 for Arab countries, US\$ 120 for foreign countries.

For all matters concerning subscription, advertisement and publication of articles, news, etc., please write to the Secretariat General.

\section{Affiliation}

The Association is an affiliate member to IUGS and AAPG.

The Executive Bureau of the Association is putting strong emphasis on applied geology in oil, mineral and construction industries, irrigation and agriculture as well as in the conservation of environment. The Bureau is continuing its cooperation with IUGS, and planning for cooperation with UNESCO and other international organizations for the fulfillment of the Association's objectives in the Arab world.

The Director of the Consulting Bureau is the Secretary General of the Association Dr. Wissam S. Al-Hashimi.

For further information about the Arab Geologists' Association, please contact:

\section{Dr. Wissam S. Al-Hashimi}

Secretary General

Arab Geologists Association

P.O. Box 28342

Al-Karkh Post Office - Al-Dawoodi

Baghdad 12631

IRAQ

TA1 . NKA $155610 \Omega$ 